\title{
REKRUTMEN DAN SELEKSI TENAGAPENDIDIKAN (GURU) UNTUK MENINGKATKAN KUALITAS PENDIDIKAN DI SMA UNGGULAN BERBASIS PESANTREN AMANATUL UMMAH PACET
}

\author{
Mizanul Hasanah \\ Institut Pesantren KH. Abdul Chalim Mojokerto, Indonesia \\ Email: mizanulhazanah@gmail.com
}

\begin{abstract}
ABSTRAK
Tujuan utama dilakukannya rekrutmen dan seleksi adalah untuk mendapatkan tenaga pendidik yang mampu mewujudkan tujuan pendidikan terutama di Indonesia. Kebijakan ini merupakan tahap pertama yang sangat penting dan perlu diterapkan seluruh lembaga pendidikan dalam rangka menjaga stabilitas mutu atau kualitas pendidikan yang diharapkan. Teknik pengumpulan data dilakukan dengan observasi, wawancara, dan dokumentasi. Hasil penelitian ini menunjukkan bahwa (1) rekrutmen yang dilakukan di SMA Unggulan Berbasis Pesantren Amanatul Ummah Pacet dilaksanakan setiap tahun. Baik itu bertujuan untuk memenukan guru baru dengan jabatan atau posisi yang kosong maupun posisi tambahan. (2) Seleksi yang dilakukan di SMA Unggulan Berbasis Pesantren Amanatul Ummah Pacet dilaksanakan setelah adanya rekrutmen dengan tujuan menentukan kriteria calon tenaga pendidik/guru yang sesuai kebutuhan di lembaga tersebut. Ketika rekrutmen telah dilaksanakan maka selanjutnya pelamar akan melewati tahap seleksi. (3) Salah satu cara meningkatkan kualitas pendidikan di SMA Unggulan Berbasis Pesantren Amanatul Ummah Pacet adalah melalui proses rekrutmen dan seleksi yang baik. Antara lain adalah dengan memilih produk unggul melalui rekrutmen dan seleksi guru yang selektif/ketat yang bertujuan untuk menghasilkan produk unggul yang berkualitas).
\end{abstract}

Kata Kunci: Rekrutmen, Seleksi, Kualitas Pendidikan

\begin{abstract}
The main purpose of recruitment and selection is to get educators who are able to realize the goals of education, especially in Indonesia. This policy is a very important first step and needs to be implemented by all educational institutions in order to maintain the expected quality of education. Data collection techniques carried out by observation, interviews, and documentation. The results of this study indicate that (1) the recruitment carried out in the High Schools Based on Pesantren Amanatul Ummah Pacet is held every year. Whether it aims to find new teachers with vacant positions or positions or additional positions. (2) Selection is carried out in the High Schools Based on the Islamic Boarding School of Amanatul Ummah Pacet conducted after the recruitment with the aim of determining the criteria for prospective educators / teachers
\end{abstract}


according to the needs of the institution. When recruitment has been carried out, the applicants will then pass the selection stage. (3) One way to improve the quality of education in the High Schools Based on Pesantren Amanatul Ummah Pacet is through a good recruitment and selection process. Among others, by selecting superior products through recruitment and selection of teachers who are selective / rigorous which aims to produce quality superior products).

Keywords: Recruitment, Selection, Quality of Education

\section{Pendahuluan}

Peningkatan kualitas pendidikan di Indonesia kembali perlu dipertanyakan pencapaiannya karena indeks pembangunan pendidikan di Indonesia mengalami penurunan. Jika pada 2010 lalu Indonesia berada di peringkat 65, maka di tahun ke-5 perolehan Indonesia merosot ke peringkat 69. Berdasarkan data dalam Education For All (EFA) Global Monitoring Report 2011, indeks pembangunan pendidikan Indonesia berdasarkan data tahun 2008 adalah 0,934. Nilai ini menempatkan Indonesia di posisi ke-69 dari 127 negara di dunia, yang artinya peningkatan kualitas pendidikan di Indonesia belum menemukan titik yang jelas, sekalipun pemerintah telah mengalokasikan anggaran pendidikan minimal $20 \%$ dari APBN sejak tahun $2009^{1}$.

Salah satu penyebab rendahnya kualitas pendidikan di Indonesia adalah rendahnya kualitas tenaga pendidik (guru) ${ }^{2}$. Dewasa ini keadaan guru di Indonesia masih perlu menjadi perhatian yang serius. Kebanyakan guru belum memiliki profesionalisme yang memadai untuk menjalankan tugasnya sebagaimana disebut dalam pasal 39 undang-undang No 20 tahun 2003 yaitu merencanakan pembelajaran, melaksanakan pembelajaran, menilai hasil pembelajaran, melakukan pembimbingan, melakukan pelatihan,melakukan penelitian dan melakukan pengabdian masyarakat ${ }^{3}$.

\footnotetext{
${ }^{1}$ Mustari Mohamad, Manajemen Pendidikan (Jakarta: RajaGrafika Persada, 2014).

${ }^{2}$ Desi Eri Kusumaningrum, Raden Bambang Sumarsono, and Imam Gunawan, 'Problematika Pemberdayaan Dan Pengembangan Sumber Daya Manusia Di Sekolah Menengah Pertama Berbasis Pesantren', Ilmu Pendidikan: Jurnal Kajian Teori Dan Praktik Kependidikan 2, no. 2 (29 December 2017): 139-50, https://doi.org/10.17977/um027v2i22017p139.

${ }^{3}$ Mohamad, Manajemen Pendidikan.
} 
Guru merupakan faktor penentu tinggi rendahnya kualitas hasil pendidikan ${ }^{4}$. Namun demikian, posisi strategis guru untuk meningkatkan mutu hasil pendidikan sangat dipengaruhi oleh kemampuan profesional, faktor kesejahteraannya, dan lainnya. ${ }^{5}$ Dewasa ini persoalan guru masih ada muncul yaitu dengan jumlah kekurangan guru yang cukup besar khususnya di daerah-daerah terpencil maka kita juga tidak dapat berharap akan terciptanya kualitas pendidikan ${ }^{6}$.

Kualifikasi pendidik juga tergantung dari institusi pendidikan guru yang ada. Jika akan mengukur kualitas dan kompetensi guru, tentu tidak dapat dilepaskan dari lembaga pendidikan yang melahirkan guru. Pendidikan guru di Indonesia dikenal dengan IKIP (Institut Keguruan dan Ilmu Pendidikan) yang kemudian bertransformasi menjadi Universitas Keguruan $^{7}$. Selain itu, ada FKIP yang terdapat di universitas-universitas negeri maupun swasta. Sedangkan lembaga pendidikan yang mencetak guru pendidikan agama Islam dikenal dengan UIN, IAIN, dan STAIN $^{8}$.

Keberhasilan sekolah untuk mendapatkan SDM yang berkualitas tidak lepas dari upaya pihak sekolah untuk mengadakan proses rekrutmen yang baik ${ }^{9}$. Rekrutmen yang berhasil menghasilkan guru yang baik sesuai standar yang diinginkan. Dengan demikian rekrutmen guru/tenaga pendidik merupakan halyang sangat penting dilakukan berdasarkan dengan kebutuhan dan persyaratan yang ditentukan oleh sekolah agar mendapatkan SDM yang berkualitas dan profesional di bidangnya. Sebaliknya jika proses rekrutmen yang dilakukan tidak selektif maka akan menghasilkan SDM yang tidak berkualitas dan tidak berkompeten di bidangnya.

\footnotetext{
${ }^{4}$ Muhammad Anas Ma`arif, 'Analisis Konsep Kompetensi Kepribadian Guru PAI Menurut Az-Zarnuji', ISTAWA 2, no. 2 (2017): 35-60; Muhammad Anas Maarif and Muhammad Husnur Rofiq, 'Pola Pengembangan Kurikulum Pendidikan Pesantren Berkarakter : Studi Implementasi Pendidikan Berkarakter di Pondok Pesantren Nurul Ummah Mojokerto' 13 (2018): 16.

5 Achmad Habibullah, 'Kompetensi Pedagogik Guru', EDUKASI: Jurnal Penelitian Pendidikan Agama Dan Keagamaan 10, no. 3 (2012), https://doi.org/10.32729/edukasi.v10i3.169.

${ }^{6}$ Mohamad, Manajemen Pendidikan.

7 Trianto dan Titiek Triwulan, Sertifikasi Dan Upaya Peningkatan Kualifikasi Kompetensi Kesejahteraan Guru (Jakarta: Prestasi Pustaka Publisher, 2014).

8 Miftahur Rohman, 'PROBLEMATIKA GURU DAN DOSEN', Cendikia: Jurnal Pendidikan Dan Kemasyarakatan Vol.14 No. (2016): 49-71.

${ }^{9}$ Ari Kartiko and jaya Roza Azzukhrufi, 'Pengaruh Budaya Organisasi Dan Kompensasi Terhadap Kinerja Pendidik Di Madrasah Aliyah Nahdlatul Ulama Mazro’atul Ulum Paciran', Nidhomul Haq : Jurnal Manajemen Pendidikan Islam 4, no. 2 (5 September 2019): 207-26, https://doi.org/10.31538/ndh.v4i2.351.
} 
Berdasarkan studi pendahuluan yang dilakukan oleh peneliti terdapat informasi terkait rekrutmen tenaga pendidik (guru). Hasil wawancara pada saat peneliti melakukan observasi pada salah satu narasumber yang merupakan salah satu tenaga pendidik di SMA Unggulan Berbasis Pesantren Amanatul Ummah Pacet. Observasi awal tentang rekrutmen tenaga pendidik (guru) di SMA Unggulan Amanatul Ummah Pacet menunjukkan bahwa adanya kegiatan rekrutmen tenaga pendidik dengan mempertimbangkan hal-hal sebagai syarat menjadi tenaga pendidik dan pengajar khususnya di lembaga Amanatul Ummah.

Berdasarkan asumsi yang peneliti temukan bahwa SMA Unggulan Berbasis Pesantren Amanatul Ummah Pacet memiliki citra yang baik di mata masyarakat. Hal ini dapat dibuktikan dengan banyaknya prestasi yang telah diraih oleh SMA berbasis Pesantren Amanatul Ummah Demi mempertahankan citra itu maka kualitas pembelajaran di SMA berbasis Pesantren Amanatul Ummah Pacet harus dipertahanakan bahkan harus ditingkatkan. Karena guru adalah ujung tombak dari penyelenggaraan pendidikan di SMA Unggulan Berbasis Pesantren Amanatul Ummah Pacet maka rekrutmen adalah salah satu cara untuk mencari bibit tenaga pendidikan yang berkualitas.

Selain unggul dengan adanya program Tahfidzul Qur'an, SMA tersebut juga unggul dalam bidang prestasi siswa. terbukti dengan banyaknya siswa yang diterima di Perguruan Tinggi Negeri dengan jurusan konsentrasi yang bergengsi, merupakan suatu pencapaian yang besar bagi lembaga tersebut. Hal ini sampaikan pada oleh salah satu fungsionaris selaku sebagai Wakil Kepala Bidang Keguruan di lembaga tersebut bahwa bukan hal yang mudah untuk mendapatkan prestasi tersebut apalagi tuntutan menghafal Al-qur'an diiringi dengan prestasi akademik ${ }^{10}$.

Penelitian yang dilakukan di SMA Unggulan Berbasis Pesantren ini dilakukan untuk mengetahuI bagaimana proses rekrutmen dan seleksi dalam meningkatkan kualitas pendidikan yang meliputi guru dan siswa sehingga dari proses tersebut menghasilkan keluaran yang unggul dalam hal ini adalah siswa. melalui proses rekrutmen dan seleksi tersebut.

\section{Metode Penelitian}

${ }^{10}$ Wawancara Fungsionaris 
Metode penelitian yang digunakan dalam penelitian ini adalah penelitian kualitatif dengan pendekatan studi kasus deskripsi eksplanatif. Pada Penelitian kualitatif ini dilakukan karena peneliti ingin mengeksplor fenomena-fenomena yang tidak dapat dikuantifikasikan yang bersifat deskriptif. Dengan demikian, penelitian kualitatif tidak hanya sebagai upaya mendeskripsikan data tetapi deskripsi tersebut hasil dari pengumpulan data yang valid yaitu melalui wawancara mendalam, observasi dan dokumentasi.

Alat pengumpulan data atau instrumen penelitian adalah peneliti sendiri,yang langsung terjun ke lapangan. Dalam pendekatan studi kasus, peneliti dimungkinkan untuk mempertahakan karakter holistic dan makna dalam peristiwa-peristiwa kehidupan nyata ${ }^{11}$.

Metode kualitatif sebagai metode penelitian yang menghasilkan kata-kata tertulis atau secara lisan dari orang-orang dan perilaku yang diamati, dalam hal ini akan diungkapkan kondisi yang nyata tentang rekrutmen rekrutmen dan seleksi tenaga pendidik dalam peningkatan kualitas pendidikan pendidikan di SMA Unggulan Berbasis Pesantren Amanatul Ummah Pacet. Penelitian ini bertujuan untuk mengetahui tentang manajemen rekrutmen dan seleksi tenaga pendidik dalam peningkatan kualitas pendidikan yang ada di SMA Unggulan Berbasis Pesantren Amanatul Ummah Pacet.

\section{Pembahasan}

1. Sumber Daya Manusia

Mangkunegara mengatakan manajemen sumber daya manusia dapat didefenisikan sebagai suatu pengelolaan dan pendayagunaan sumber daya yang ada pada individu. Selanjutnya, manajemen sumber daya manusia merupakan suatu perencanaan, pengorganisasian, pelaksanaan dan pengawasan terhadap pengadaan, pengembangan, pemberian balas jasa, pengintegrasian, pemeliharaan, dan pemisahan tenaga kerja dalam rangka mencapai tujuan organisasi ${ }^{12}$.

${ }^{11}$ Zein M Muktaf, 'T Eknik Penelitian Studi Kasus , Etnografi Dan Fenomenologi Dalam Metode Kualitatif', 2016, 1-5.

${ }^{12}$ Lijan Poltak Sinambela, Manajemen Sumber Daya Manusia / Lijan Poltak Sinambela ; Editor, Suryani, ed. 1 cet. 1 (Bumi Aksara, 2016). 


\section{Rekrutmen}

Definisi rekrutmen menurut Siagian, adalah proses mencari, menemukan, dan menarik pelamar untuk dipekerjakan dalam suatu organisasi ${ }^{13}$. Sedangkan menurut Mangkunegara mengemukakan bahwa: Recruitment is the act or process of anorganization attempting to obtain additional manpower for oprtational purpose. Recruiting involves acquiring further human resources to serveas institusional input. Penarikan pegawai adalah tindakan atau proses dari suatu usaha organisasi untuk mendapatkan tambahan pegawai untuk tujuan operasional ${ }^{14}$.

Defenisi rekrutmen, menurut beberapa ahli seperti yang dikemukakan oleh Werther and Davis, bahwa rekrutmen adalah proses penemuan dan penerimaan dari pelamar-pelamar yang cukup untuk menempati suatu posisi jabatan. Proses dimulai perekrutan mencari sebanyak banyaknya pelamar dan berakhir ketika menerima surat lamaran. Berbeda sedikit dengan Werther and Davis, defenisi rekrutmen menurut T.Hani Handoko, bahwa rekrutmen adalah proses mencari, menemukan, dan menarik pelamar yang kapabel untuk dipekerjakan dalam dan oleh suatu organisasi. Sedangkan menurut Malayu P Hasibuan dalam buku M.Yani , rekrutmen adalah proses penarikan, seleksi, penempatan, orientasi dan induksi untuk mendapatkan karyawan yang efektif dan efisien untuk membantu tercapainya tujuan perusahaan. Hal ini jika proses rekrutmen dilakukan dalam mencari karyawan atau tenaga kerja di sebuah perusahaan $^{15}$.

Kemudian dari beberapa pendapat yang dikemukakan oleh para ahli diatas peneliti menarik kesimpulan bahwa rekrutmen adalah segala aktivitas suatu organisasi baik pada lembaga pendidikan, perusahaan, maupun suatu organisasi tertentu. Yang mana aktivitas tersebut mempengaruhi sejumlah dan berbagai tipe pelamar. Semakin banyak jumlah pelamar maka rekrutmen tersebut berhasil dan apakah pelamar tersebut menerima pekerjaan yang ditawarkan.

Dalam praktiknya pelaksanaan rekrutmen memiliki beberapa tujuan yang ingin dicapai yaitu :

${ }^{13}$ Sondang P.Siagian, Manajemen Sumber Daya Manusia (Jakarta: Pt. Bumi Aksara, 2009), 102.

${ }^{14}$ Anwar Prabu, Manajemen Sumber Daya Manusia (Jakarta: Rineka Cipta, 2011), 33.

${ }^{15}$ M Yani, Manajemen Sumber Daya Manusia (Jakarta: Mitra Wacana Media, 2012), 73. 
a) Memperoleh sumber tenaga yang potensial

b) Memperoleh sejumlah pelamar yang memenuhi kualifikasi

c) Menentukan kriteria minimal untuk calon pelamar untuk keutuhan seleksi ${ }^{16}$

Dalam rangka mendapatkan calon guru yang professional, memenuhi kualifikasi,dan menjanjikan untuk menduduki posisi tertentu tidaklah mudah. Ada beberapa prinsip yang harus dipegang teguh dalam perencanaan atau pelaksanaan rekrutmen guru, diantaranya:

a) Rekrutmen guru harus dirancang secara matang agar dapat memenuhi kebutuhan.

b) Rekrutmen guru harus dilakukan secara objektif. Artinya panitia seleksi pegawai baru menetapkan pelamar yang lulus dan pelamar yang tidaklulus secara objektif. Pelamar yang tidak memenuhi persyaratan secara objektif dinilai tidak lulus, dan sebaliknya pelamar yang memenuhi persyaratan ditetapkan sebagai pelamar yang lulus.

c) Agar didapatkan calon yang professional, sebaiknya materi seleksi pegawai baru harus komprehensif mencakup semua aspek persyaratan yang harus dimiliki oleh calon guru ${ }^{17}$.

Langka tindaknya keahlian atau keterampilan tertentu dipasaran kerja, tersedia tidaknya orang memilih pengetahuan dan keterampilan tertentu itu tidaklah konstan, bisa saja suatu ketika terjadi kelangkaan orang yang memiliki keahlian tertentu. Dengan demikian sikap dan tindakan para pencari tenaga kerja baru berbeda dibandingkan jika tidak menghadapi suasana kelangkaan. Hal ini berkaitan dengan berbagai faktor demografi, seperti laju pertumbuhan penduduk, dari segi jenis kelamin, jumlah dan jenis keluaran lembaga pendidikan.

Dari proyeksi tersebut para pencari tenaga kerja dapat memperkirakan apakah jumlah pelamar akan banyak dan dengan kualifikasi yang bagaimana. Adapun langkah-langkah yang ditempuh dalam proses rekrutmen menurut Siagian, adalah penerimaan surat lamaran, penyelenggaraan ujian, dan wawancara ${ }^{18}$.

3. Seleksi

${ }^{16}$ kasmir, Manajemen Sumber Daya Manusia Teori Dan Praktik (Jakarta: Rajawali Pers, 2012), 9.

${ }^{17}$ Ibrahim Bafadal, Peningkatan Profesionalisme Guru Sekolah Dasar (Jakarta: Bumi aksara, 2008), 22.

${ }^{18}$ P.Siagian, Manajemen Sumber Daya Manusia, 137. 
Seleksi adalah suatu proses pemilihan calon tenaga kerja yang paling memenuhi syarat untuk mengisi suatu lowongan pekerjaan. Badriyah mengungkapkan bahwa rekrutmen adalah tindakan atau proses dari suatu usaha organisasi untuk mendapatkan tambahan pegawai untuk tujuan operasional ${ }^{19}$. Seleksi dalam hal ini adalah bagian dari proses rekrutmen.

Adapun tahapan rekrutmen pegawai/ calon pendidik yang dilakukan secara $\operatorname{tradisional}^{20}$ :

1) Memperjelas posisi yang harus di isi dalam proses perekrutan

2) Review dan memperbaharui uraian pekerjaan dan spesifikasi untuk posisi tersebut

3) Mengidentifikasi kemungkinan sumber pelamar yang memenuhi syarat

4) Pilih cara komunikasi yang lebih baik

Oleh karena itu, suatu organisasi harus menemukan cara untuk membangun pemahaman bahwa organisasi merupakan tempat yang baik untuk bekerja. Jika dalam ranah pendidikan maka suatu lembaga memiliki tugas untuk menjadikan lembaga sebagai tempat terbaik untuk bekerja bagi seluruh personalia. Pedekatan khusus dalam rekrutmen bisa dilakukan juga dalam dunia maya dengan website yang mampu menjangkau pelamar dari berbagai lokasi geografis yaitu dengan melakukan postingan lowongan pekerjaan di internet sehingga kebutuhan pegawai yang berkualifikasi global dapat dipenuhi oleh organisasi ${ }^{21}$.

Menurut Sirait, seleksi penerimaan pegawai bertujuan untuk mendapatkan: (1) Pegawai yang qualified dan potensial, (2)Pegawai yang jujur dan berdisiplin (3) Pegawai yang cakap dan penempatannya yang tepat (4) Pegawai yang terampil dan bersemangat dalam bekerja (5) Pegawai yang memenuhi persyaratan undang-undang kepegawaian (6) Pegawai yang dapat bekerja sama baik secara vertikal maupun horizontal (7) Pegawai yang dinamis dan kreatif (8) Pegawai yang inovatif dan bertanggung jawab sepenuhnya (9) Pegawai yang loyal dan berdedikasi tinggi (10) Mengurangi tingkat absensi dan turnover karyawan (11) Pegawai yang mudah

\footnotetext{
${ }^{19}$ Mila Badriyah, Manajemen Sumber Daya Manusia (Bandung: Pustaka Setia, 2015), 53.

${ }^{20}$ lijan poltak s, Manajemen Sumber Daya Manusia (Jakarta: Bumi aksara, 2016).

${ }^{21}$ lijan poltak s, 127.
} 
dikembangkan pada masa depan (12) Pegawai yang dapat bekerja secara mandiri (13) Pegawai yang mempunyai perilaku dan budaya malu ${ }^{22}$.

Adapun kriteria seleksi menurut Simamora pada umumnya dapat dirangkum dalam berbagai kategori, yaitu : (a) Pendidikan (b)Pengalaman kerja (c)Tes mengenai hal-hal yang berhubungan dengan kerja (d)Pusat pelatihan (e) Biodata (f) Refrensi. Sedangkan langkah-langkah dalam seleksi yaitu : (a) Seleksi surat-surat lamaran (b) Pengisian blanko lamaran (c)Pemeriksaan refrensi (d)Wawancara pendahuluan (e)Tes penerimaan(f)Tes psikolog (g) Tes kesehatan (h)Wawancara akhir atasan langsung: memutuskan diterima atau ditolak serta penempatan karyawan yang sesuai ${ }^{23}$.

Implementasinya tetap saja diperoleh berbagai hambatan. Hal itu disebabkan oleh yang diseleksi adalah manusia yang memiliki pikiran, dinamika, dan harga diri hal ini yang dimaksud oleh Badriyah. Berikut ini berbagai hambatan yang dimaksud ${ }^{24}$ :

a) Tolak ukur. Hal yang dimaksud dengan tolak ukur adalah kesulitan yang dihadapi dalam menentukan standar yang tepat digunakan dalam menggapai berbagai kualifikasi yang ditentukan.

b) Penyeleksi. Hambatan penyeleksi adalah kesulitan mendapatkan penyeleksi yang profesional, jujur, dan objektif dalam melaksanakan tugasnya.

c) Persepsi tentang seleksi. Hakikat seleksi tidak semua orang mempersepsikannya. Dalam hal ini, terdapat kesenjangan persepsi antara manajemen dengan penyeleksi yang ditugaskan sehingga penerapan prinsip-prinsip seleksi tidak dilakukan dengan baik dan benar.

d) Hasil seleksi versus pembiayaan. Manajemen mengharapkan hasil seleksi yang objektif dilakukan, tetapi tidak memfasilitasi pembiayaan yang diajukan.

Kejujuran pelamar. Dalam hal ini, pelamar memperoleh hambatan dengan memberikan jawaban yang jujur. Pada umumnya, pelamar akan memberikan jawaban tentang yang baik saja akan dirinya, sedangkan yang kurang baik umumnya disembunyikan.

${ }^{22}$ Badriyah, Manajemen Sumber Daya Manusia, 109.

${ }^{23}$ Simamora, Rekrutmen Dan Seleksi (Jakarta: Pt.Bukan Bintang, 2014), 98.

${ }^{24}$ Badriyah, Manajemen Sumber Daya Manusia, 143. 
4. Tenaga Pendidik

Pendidik adalah guru atau orang yang berpendidikan sedangkan guru adalah orang yang mengajari orang lain baik disekolah atau bukan tentang suatu ilmu pengetahuan atau tentang keterampilan maksudnya yaitu bahwa tenaga pendidik atau guru adalah orang bekerja untuk menyampaikan suatu ilmu tentang suatu keterampilan. Syaiful Bahri Djamarah dalam Pupuh Faturrohman, mendefinisikan guru sebagai tenaga pendidik yang memberikan sejumlah ilmu pengetahuan kepada anak didik ${ }^{25}$.

Pendidik harus memiliki kualifikasi akdemik dan kompetensi sebagai agen pembelajaran, sehat jasmani dan rohani, serta memiliki kemampuan untuk mewujudkan tujuan pendidikan nasional. Kualifikasi akademik yang dimaksud di atas adalah tingkat pendidikan minimal yang harus dimiliki seorang pendidik yang dibuktikan dengan ijazah dan atau sertifikat keahlian yang relevan sesuai ketentuan perundang-undangan yang berlaku ${ }^{26}$.

Oleh karena itu masyarakat kita masih sangat mengaharapkan sosok guru yang dapat menjadi panutan dan teladan yang baik bagi anak-anak mereka sebagai peserta didik juga bagi orang tua dan masyarakat sekitar pada umumnya. Sehingga masyarakat merasa aman dan nyaman menitipkan putra putinya kepada guru yang bertanggung jawab terhadap tugasnya sebagi pendidik.

\section{Kualitas Pendidikan}

Pada standar ini pendidik harus memiliki kualifikasi akademik dan kompetensi sebagai agen pembelajaran harus sehat jasmani dan rohani, serta memiliki kemampuan untuk mewujudkan tujuan pendidikan nasional. Kualifikasi akademik yang dimaksudkan di atas adalah tingkat pendidikan minimal yang harus dipenuhi oleh

\footnotetext{
${ }^{25}$ Bafadal, Peningkatan Profesionalisme Guru Sekolah Dasar, 473.

${ }^{26}$ Undang-undang SISDIKNAS Nomor 20 tahun 2003, hlm.30.
} 
seorang pendidik yang dibuktikan dengan ijazah dan/atau sertifikat keahlian yang relevan sesuai ketentuan perundang-undangan yang berlaku. Kompetensi akademik adalah tingkatan pendidikan minimal yang harus dipenuhi seorang pendidik sebagai tolak ukur dalam standar pendidkan dan tenaga kependidikan.

Seperti yang dikemukakan oleh Goetsch and Davis memberikan definisi tentang kualitas adalah sebagai berikut. "Quality is dynamic state associate with product, service, people, process, and environments that metts or exceeds expectations". Kualitas merupakan pernyataan yang dinamis yang terkait dengan produk, pelayanan, orang, proses dan lingkungan yang dapat memenuhi atau melebihi yang diharapkan ${ }^{27}$.

Sebagai seseorang yang berperan penting dalam proses kemajuan kualitas pendidikan maka pendidik harus memiliki kompetensi untukmendukung utama kinerjanya. Berdasarkan Permendiknas No. 16 Tahun 2007, guru harus memiliki 4 kompentensi, antara lain: Kompetensi Pedagogik, Kompentensi Keahlian, Kompentensi Sosial dan Kompentensi Profesional.

6. Kajian Teoretik Perspektif Islam

Setelah diadakan rekrutmen maka tahap selanjutnya adalah seleksi yang mana calon yang diseleksi akan diberi ujian. Ujian seleksi adalah persoalan pokok dalam Islam. Islam mendorong umatnya untuk memilih calon pegawai berdasarkan pengetahuan, pengalaman dan kemampuan teknis yang dimiliki. Hal tersebut sesuai dengan firman Allah SWT dalam QS: Al- Qashas : 26

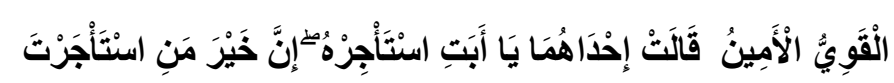

Salah seorang dari kedua wanita itu berkata: "Ya Bapakku ambillah ia sebagai orang yamg bekerja (pada kita), karena sesungguhnya orang yang paling baik yang kamu ambil untuk bekerja (pada kita) ialah orang yang kuat lagi dapat dipercaya”.

${ }^{27}$ Sabar Budi Raharjo, 'Evaluasi Trend Kualitas Pendidikan Di Indonesia', Jurnal Penelitian Dan Evaluasi Pendidikan 16, no. 2 (2013): 511-32, https://doi.org/10.21831/pep.v16i2.1129. 
Islam memandang khususnya pada bidang pendidikan, seseorang harus benar-benar mempunyai kualitas keilmuan kependidikan dan keinginan yang memadai guna menunjang tugas jabatan profesinya terdapat dalam Qur'an Surah Al Isra' : 84

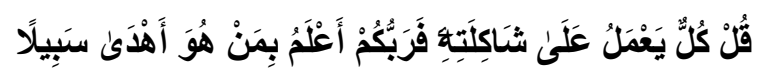

Katakanlah: "Tiap-tiap orang berbuat menurut keadaannya masing-masing". Maka Tuhanmu lebih mengetahui siapa yang lebih benar jalannya.

$$
\text { إن هذا العلم دين فانظروا عمن تأخذون دينكم }
$$

"Sesungguhnya ilmu ini adalah agama, maka lihatlah dari siapakah kalian mengambil agama kalian" (Diriwayatkan oleh Muslim dalam muqaddimah kitab Shahih-nya 1/7 Maktabah Sahab).

Dalam memilih seorang pendidik menurut Az-Zarnuji mengacu pada sumber data primer yaitu, Kitab Ta'alimul Muta'alim yaitu memilih guru, hendaklah memilih siapa yang lebih alim, lebih waro' dan lebih berusia, seperti halnya Imam Abu Hanifah menjatuhkan pilihannya pada Hammad bin Sulaiman setelah terlebih dahulu berfikir dan mempertimbangkan

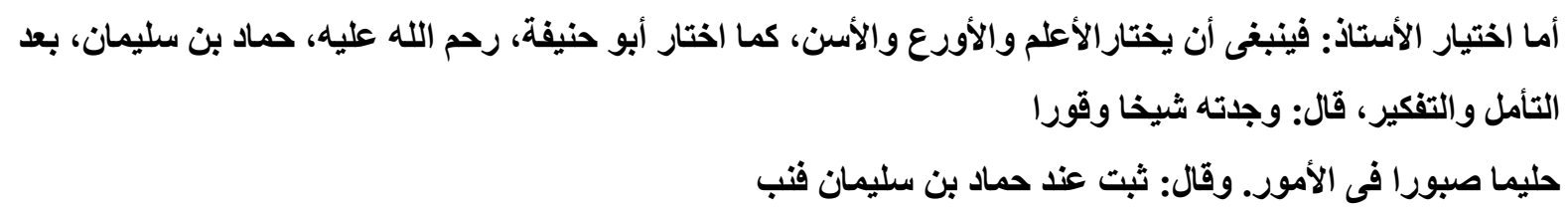

Dalam memilih guru, hendaklah mengambil yang lebih alim, wara' dan lebih tua usianya. Sebagaimana Imam Abu Hanifah setelah lebih dahulu memikir dan mempertimbangkan lebih lanjut, maka menentukan pilihannya kepada Syaikh Hammad bin Abu Sulaiman. Dalam hal ini beliau berkata: "Beliau (Syaikh Hammad) saya kenal sebagai orangtua yang berbudi luhur, lapang dada serta penyabar.” Lanjut Abu Hanifah, "Saya mengabdi pada Syaikh Hammad bin Abu Sulaiman, dan sayapun makin berkembang.

Dari uraian di atas, secara garis besar ada tiga kriteria yang harus dimiliki oleh seorang guru, yaitu: Hendaklah memilih orang yang lebih alim, hendaklah memilih 
orang lebih waro' dan Hendaklah memilih orang lebih berusia. Ketiga kriteria guru tersebut merupakan syarat untuk memilih sekaligus mengangkat seorang guru dalam suatu lembaga pendidikan.

Itulah sebabnya mengapa guru menjadi salah satu faktor yang mutlak di dalam pembangunan. Makin bersungguh-sungguh pemerintah untuk membangun negaranya, maka menjadi urgen kedudukan dan peran guru dalam pembangunan tersebut. Sehingga sudah merupakan suatu keharusan bagi suatu negara untuk memperhatikan guru dari segi kompetensi dan kesejahteraannya. Guru pada hakekatnya merupakan tenaga pendidik yang memikul beban berat tanggungjawab kemanusiaan, khususnya dalam mendidik generasi penerus bangsa menujukecerahan dan melepaskan diri dari belenggu kebodohan ${ }^{28}$.

\section{Hasil Penelitian dan Pembahasan}

1. Rekrutmen

Berdasarkan temuan yang diperoleh dari hasil wawancara beberapa narasumber bahwa rekrutmen dilakukan atas dasar kebutuhan pegawai atau tenaga kerja dan penambahan pegawai. Kondisi di lapangan menunjukkan temuan yang berbeda. Namun didukung dengan teori lainya. Hal ini senada dengan teori rekrutmen oleh Siagian, Werther dan Davis yaitu adanya formasi yang kosong pada jabatan tertentu, melewati beberapa tahapan dalam proses tersebut dan melibatkan banyak pelamar.

Selanjutnya adapun teori rekrutmen oleh Sofyandi yang senada dengan realitas yang terjadi di lapangan yaitu adanya penyesuaian antara guru dengan rombongan belajar. Dimana, Sofyandi mengemukakan terdapat dua jenis sumber internal dan eksternal. Kondisi yang terjadi dilapangan salah satunya mengutamakan sumber internal yaitu adanya job posting dan job bidding yaitu referensi pegawai lama dan rencana suksesi penggantian karyawan.

a. Tujuan rekrutmen

${ }^{28}$ Trianto dan Titiek Triwulan, Sertifikasi Dan Upaya Peningkatan Kualifikasi Kompetensi Kesejahteraan Guru, 7. 
Berdasarkan temuan yang diperoleh dari hasil wawancara beberapa narasumber bahwa tujuan rekrutmen dilakukan atas dasar sumber tenaga yang potensial seperti mengutamakan kualifikasi keterampilan dan menentukan kriteria minimal seperti mengutamakan lulusan perguruan tinggi negeri.

Kondisi di lapangan menunjukkan temuan yang berbeda dari apa yang telah dikemukakan Kasmir, namun merujuk pada teori Mangkunegara yaitu dengan adanya penambahan jumlah tenaga pendidik sesuai kebutuhan lembaga. Kemudian adanya posisi yang kosong pada suatu jabatan tertentu yang harus segera ditempati.

Selain itu, temuan berikutnya yang bersumber dari narasumber-nasrasumber lainnya adalah mempersiapkan diri sebagai tenaga pendidik di lembaga tersebut sesuai dengan keahlian dan bidang yang ditekuni. Hal ini dilakukan dengan tujuan menjadikan lembaga lebih maju kualitas pendidikannya.

b. Prinsip rekrutmen

Berdasarkan temuan yang diperoleh dari hasil wawancara beberapa narasumber bahwa prinsip-prinsip rekrutmen dilakukan atas dasar perancangan secara matang oleh tim rekrutmen, rekrutmen dilakukan secara objektif, dan professional calon pendidik seperti kompetensi keahlian yang linier, menguasai materi, teknik mengajar, komitmen, dan pengalaman .

Kondisi di lapangan menunjukkan temuan yang berbeda. Namun didukung dengan teori lainya. Hal ini senada dengan teori rekrutmen oleh Mangkunegara yaitu adanya asas kebutuhan guru yang sesuai dengan kebutuhan lembaga.

Selanjutnya adapun teori tentang prinsip-prinsip rekrutmen oleh Kasmir yang senada dengan realitas yang terjadi di lapangan yaitu mengutamankan lulusan perguruan tinggi negeri sebagai kriteria minimal. Kemudian memperoleh sumber tenaga yang potensial seperti prestasi yang ditunjukkan dengan bukti sertifikat dan penghargaan yang dimiliki oleh calon tenaga pendidik. Selain itu realitas yang terjadi dilapangan mengambarkan bahwa lembaga tersebut mengunakan prinsip bahwa setiap calon tenaga pendidik wajib mengikuti aturan yang berlaku seperti mengikuti dauroh malam dan berfaham aswaja dalam hal ini ideologi Nahdlatul Ulama.

c. Langkah-langkah Rekrutmen 
Berdasarkan temuan yang diperoleh dari hasil wawancara beberapa narasumber bahwa langkah-langkah rekrutmen dilakukan atas dasar penerimaan surat lamaran kerja, penyelenggaraan ujian, dan wawancara.

Kondisi di lapangan menunjukkan temuan yang berbeda. Namun didukung dengan teori lainya. Hal ini senada dengan teori rekrutmen oleh Kasmir pada tujuan rekrutmen yaitu menentukan kriteria minimal. Hal yang terjadi di lapangan menunjukan bahwa pada lembaga tersebut menetukan kriteria minimal dengan menetapkan setiap pelamar diutamakan berasal dari perguruan tinggi negeri.

Selain itu realitas yang terjadi di lapangan mengutamakan setiap pelamar yang sudah melewati tahap wawancara akan ditanyai ideologi Ke-NU-annya. Selanjutnya terdapat salah satu syarat dalam pemberkasan yang telah ditentukan oleh lembaga yaitu dengan menyertakan ijazah yang telah dilegalisir serta adanya surat rekomendasi untuk masuk ke tahap wawancara hasil akhir yang diadakan oleh tim akhir seleksi yang bertempat di Pusat.

\section{Seleksi}

Berdasarkan temuan yang diperoleh dari hasil wawancara beberapa narasumber bahwa seleksi dilakukan atas dasar proses pemilihan yang memenuhi syarat seperti pemantauan dan proses yang selektif.

Kondisi di lapangan menunjukkan temuan yang berbeda. Namun didukung dengan teori lainya. Hal ini senada dengan teori rekrutmen oleh Kasmir pada tujuan rekrutmen yaitu menentukan kriteria minimal. Hal yang terjadi di lapangan menunjukan bahwa pada lembaga tersebut menetukan kriteria minimal dengan menetapkan setiap pelamar diutamakan berasal dari perguruan tinggi negeri.

Selain itu realitas yang terjadi di lapangan adalah rangkaian proses seleksi pada lembaga tersebut ditunjang berdasarkan prinsip pemilik yayasan. Yang mana mengutamakan seleksi ketat dan tes keagamaan dalam hal ini tes $\mathrm{Ke} \mathrm{Nu-an} \mathrm{yang}$ mendalam. Tentang seberapa peduli pelamar terhadap NU. Selain itu adanya surat rekomendasi yang berasal dari cabang yang menyartakan bahwa pelamar tersebut sudah lulus seleksi tahap awal dan akan diproses pada tahap pusat untuk keputusan diterima 
atau ditolak. Selanjutnya adanya konfirmasi dari pusat untuk ditindaklanjuti sebagai hasil akhir dari proses seleksi tersebut.

a. Dasar dan Tujuan

Berdasarkan temuan yang diperoleh dari hasil wawancara beberapa narasumber bahwa seleksi dilakukan atas dasar kebijakan pemerintah melalui undangundang guru dan dosen serta spesifikasi pekerjaan dan jabatan.

Kondisi di lapangan menunjukkan temuan yang senada dengan teori Hasibuan bahwa kegiatan seleksi tenaga pendidik harus mengikuti undang-undang. Selain itu teori ini diperkuat dengan teori Sirait bahwa pegawai yang cakap dan penempatan yang tepat. Dalam hal ini adalah syarat guru yang mengajar harus linier dengan konsentrasi jurusan yang diambil sewaktu kuliah di perguruan tinggi asalnya.

Namun, terdapat beberapa hal yang berbeda dari teori sebelumnya. Hal yang terjadi di lapangan menunjukan bahwa segala sesuatu yang berkaitan dengan kegiatan seleksi atas perintah dari pemilik yayasan. Pada yayasan tersebut dinaungi langsung oleh sosok seorang Kyai yang dihormati. Kegiatan seleksi juga melibatkan tes keagamaan yang merupakan hal yang sangat penting untuk menentukan diterima atau ditolak calon tenaga pendidik yang telah diseleksi dan mendapat rekomendasi sebelumnya.

b. Kriteria dan Langkah-langkah Seleksi

Berdasarkan temuan yang diperoleh dari hasil wawancara beberapa narasumber bahwa kriteria seleksi dilakukan atas dasar pendidikan, pengalaman kerja, diberlakukan tes, dan track record pelamar. Selanjutnya teori Simamora tentang langkah-langkah seleksi menunjukkan hal yang senada yaitu seleksi pemberkasan lengkap, pengisian blanko, pemeriksaan referensi, wawancara awal, penerimaan awal berupa surat rekomendasi, tes psikologi, dan wawancara akhir.

Kondisi di lapangan menunjukkan temuan yang senada dengan teori Kasmir tentang menentukan kriteria minimal bahwa tenaga pendidik yang dibutuhkan lembaga tersebut adalah yang berasal dari perguruan tinggi negeri. Selanjutnya pada tahap akhir seleksi penentuan diterima atau ditolak pelamar akan di tes keagamaan berupa tes seberapa besar rasa kepedulian pada Nahdlatul Ulama. Bagian ini 
merupakan hal yang terpenting untuk dipertimbangkan diterima atau tidaknya menjadi bagian dari lembaga tersebut. dan tahap akhirnya ketika pelamar diterima maka diberi kontrak selama enam bulan masa training.

c. Hambatan Proses Seleksi

Berdasarkan temuan yang diperoleh dari hasil wawancara beberapa narasumber bahwa hambatan proses seleksi dilakukan atas dasar tolak ukur yakni berideologi Nahdlatul Ulama, tim penyeleksi (double seleksi), seleksi ketat, dan hasil seleksi legalitas kontrak diatas materai.

Kondisi di lapangan menunjukkan temuan yang berbeda. Hambatan yang dialami oleh lembaga ketika proses pemyeleksian adalah ketika mendapatkan calon pelamar yang sesuai dengan kriteria dan siap ditempatkan pada lingkungan kerja yang sesuai dengan keahliannya. Namun, pelamar tesebut adalah bukan berasal dari keluarga nahdiyin dan lebih mengacu pada background pondok pesantren yang tidak berbasis Nahdlatul Ulama. Selain itu, ketika jumlah pelamar banyak tentunya tim lebih megeluarkan waktu dan energi untuk menyeleksi secara objektif. Hal ini membutuhkan pertimbangan yang sangat panjang dan waktu yang lama. Sehingga proses seleksi akan terhambat.

\section{Kualitas Pendidikan}

Berdasarkan temuan yang diperoleh dari hasil wawancara beberapa narasumber bahwa kualitas pendidikan dilakukan atas produk yang unggul seperti asal perguruan tinggi dan proses pemilihan produk (tenaga pendidik).

Kondisi di lapangan menunjukkan temuan yang senada dengan teori Ishikawa tentang kualitas pendidikan yaitu kualitas produk yang dihasilkan. Seperti halnya tenaga pendidik yang akan diterima oleh lembaga harus berasal dari perguruan tinggu negeri. Selain itu asas etos kerja dan kualitas kerja yang mana calon pelamar harus memiliki pengalaman dan track record yang baik untuk dipertimbangkan oleh lembaga.

Mastari dalam permendiknas Nomor 16 Tahun 2007 Pasal 1 tentang standar kualifikasi akademik dan kompetensi guru adalah minimal seorang guru jenjang pendidikan minimum Strata satu dan kampus yang terakreditasi. Kondisi di lapangan 
menunjukkan bahwa calon tenaga pendidikan haruslah linier dengan konsentrasi keilmuan sewaktu duduk di bangku perkuliahan. Kemudian kualitas pendidikan di dukung oleh kualitas keilmuan berbanding lurus dengan kualitas keagamaanya yakni berideologi Nahdlatul Ulama.

Berdasarkan hasil temuan yang dilakukan peneliti pada lembaga yang diteliti terdapat proses rekrutmen dan seleksi yang bebeda dan senada dengan teori yang telah dipaparkan. Berikut rangkaian proses rekrutmen dan seleksi untuk meningkatkan kualitas pendidikan di SMA Unggulan Berbasis Pesantren Amanatul Ummah Pacet.

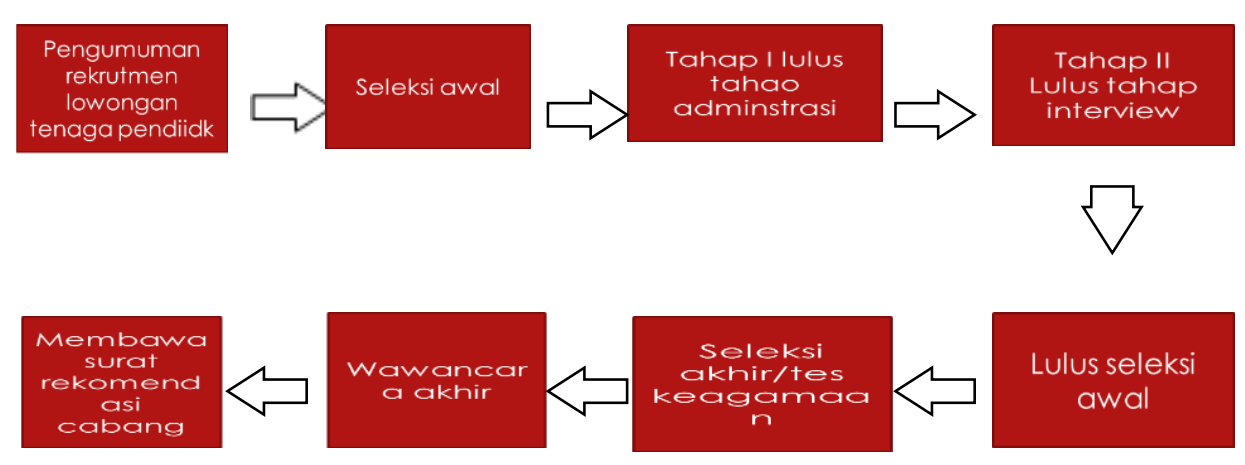

\section{Gambar 2.1. Proses Rekrutmen Dan Seleksi Sumber: Olah data Hasil Penelitian}

\section{Kesimpulan}

Rekrutmen yang dilakukan di SMA Unggulan Berbasis Pesantren Amanatul Ummah Pacet dilaksanakan setiap tahun. Baik itu bertujuan untuk memenukan guru baru dengan jabatan atau posisi yang kosong maupun posisi tambahan. Berdasarkan hasil temuan proses rekrutmen yang dilakukan di lembaga meliputi proses sebagai berikut: pertama, lembaga memberi pemberitahuan bahwa adanya lowongan sebagai guru dengan posisi dan kriteria tertentu. Kedua, melampirkan persayaratan awal seperti administrasi seperti penerimaan surat lamaran. Pada proses ini adalah tim rekrutmen mencocokan syarat dan kriteria yang telah di tentukan oleh ketua yayasan. Seperti, kriteria minimal lulusan strata-1 dan berlatar belakang dari perguruan tinggi negeri (PTN). Ketiga, pelamar yang lulus pada tahap administrasi selanjutnya akan melewati ujian berupa interview atau wawancara dengan tim rekrutmen dan 
guru senior. Keempat, pelamar yang lulus tahap interview atau wawancara selanjutnya akan melewati tahapan tes micro teaching serta didampingi langsung guru senior. Kelima, pada tahap akhir ini pelamar langsung dinyatakan lulus atau tidak lulus oleh lembaga internal (cabang). Jika calon tenaga pendidik/guru yang dites bidang muadalah maka akan dites kitab kuning dan hafalan Al Qur'an sedangkan calon tenaga pendidik/guru yang dites bidang formal atau akademik maka akan dites sesuai dengan keterampilan dan konsentrasi pendiidkan sebelumnya.

Adapun lembaga tersebut melakukan tahap rekrutmen tenaga pendidik/guru dengan memperhatikan tujuan rekrutmen yaitu atas dasar sumber daya yang potensial seperti mengutamakan kualifikasi keterampilan dan kriteria minimal seperti mengutamakan calon tenaga pendidik harus berlatar belakang dari perguruan tinggi negeri (PTN), prinsip-prinsip rekrutmen yang mana dilakukan atas perancangan yang matang, objektif, professional oleh tim rekrutmen seperti keahlian, penguasaan materi, teknik mengajar, komitmen, dan pengalaman calon tenaga pendidik, dan langkah-langkah rekrutmen seperti penerimaan surat lamaran pekerjaan, penyelenggaraan ujian, dan wawancara serta adanya surat rekomendasi untuk ditindaklanjuti.

Seleksi yang dilakukan di SMA Unggulan Berbasis Pesantren Amanatul Ummah Pacet dilaksanakan setelah adanya rekrutmen dengan tujuan menentukan kriteria calon tenaga pendidik/guru yang sesuai kebutuhan di lembaga tersebut. Ketika rekrutmen telah dilaksanakan maka selanjutnya pelamar akan melewati tahap seleksi. Adapun tahap seleksi yang dilaksanakan meliputi: pertama, pelamar yang lulus tahap lulus proses rekrutmen akan mendapatkan surat rekomendasi untuk kembali menjalakan tes lembaga yang berada di pusat. Tes ini langsung ditangani oleh pihak yang telah diberi wewenang oleh lembaga. Kedua, Selanjutnya pelamar akan melewatu tes kemampuan, keahlian, komitmen, dan psikologi. Ketiga, pada tahap ini akan dilakukan seleksi akhir yaitu tes keagamaan. Yakni mengetahui seberapa jauh kepedulian pelamar pada Nahdlatul Ulama oleh tim penentu akhir. Keempat, pada tahap penentuan ini pelamar akan mengetahui keputusan pihak lembaga diterima atau sebaliknya untuk mengabdi dilembaga tersebut sebagai tenaga pendidik. Jika pelamar dinyatakan lulus maka selanjutnya akan mendatangani kontrak kerja dan bersedia mengikuti 
training selama enam bulan dengan tujuan untuk mengetahui perkembangan dan kemajuan tenaga pendidik tersebut.

Tujuannya adalah untuk mengetahui apakah tenaga pendidik tersebut layak atau tidaknya menjadi staff pengajar tetap di lembaga tersebut. Sejalan dengan hal itu lembaga memperhatikan terlebih dahulu dasar seleksi sebagaimana bagian dari kebijakan pemerintah dalam undang-undang dan spesifkasi pekerjaan atau jabatan, tujuan seleksi yang mana ingin mendapatkan pegawai yang potensial, pegawai yang jujur dan disiplin, pegwai yang cakap dalam penempatannya, dapat bekerja sama dengan baik pegawai yang loyalitas dan berdedikasi tinggi, serta pegawai yang mudah dikembangkan kedepannya. Selanjutnya adapun memperhatikan kriteria seleksi dilakukan atas dasar pendidikan, pengalaman kerja, dan track record pelamar. Sedangkan hambatan proses seleksi adalah tolak ukur yang ditetapkan pada suatu lembaga seperti di SMA Unggulan Berbasis Pesantren Amanatul Ummah Pacet mengharuskan setiap tenaga pendidik berideologi NU. Ketika mendaptkan tenaga pendidik yang sesuai kriteria yang diinginkan namun karena tidak peduli dan tidak berideologi NU maka calon tenaga pendidik akan dipertimbangkan bahkan ditolak.

Salah satu cara meningkatkan kualitas pendidikan di SMA Unggulan Berbasis Pesantren Amanatul Ummah Pacet adalah melalui proses rekrutmen dan seleksi yang baik. Antara lain adalah dengan memilih produk unggul melalui rekrutmen dan seleksi guru yang selektif/ketat yang bertujuan untuk menghasilkan produk unggul yang berkualitas). Produk unggul yang dibahas disini adalah peserta didik. Hal ini sejalan dengan tujuan pendidikan yakni lembaga atau sekolah yang berkualitas adalah sekolah yang mampu menghasilkan produk peserta didik yang unggul dan mampu bersaing dalam dunia kerja Jika input (guru) yang diperbaiki kualitasnya untuk menjadi tenaga pendidik/guru maka harapannya adalah akan dihasilkan produk unggul sebagai output. Tentunya proses adalah hal yang paling penting untuk meningkatkan kualitas pendidikan. Dengan melakukan langkah langkah untuk terus mengembangkan dan mengupayakan agar input dan output dapat sejalan dengan tujuan pendidikan. 


\section{Daftar Pustaka}

Badriyah, Mila. Manajemen Sumber Daya Manusia. Bandung: Pustaka Setia, 2015.

Bafadal, Ibrahim. Peningkatan Profesionalisme Guru Sekolah Dasar. Jakarta: Bumi aksara, 2008.

Habibullah, Achmad. 'Kompetensi Pedagogik Guru'. EDUKASI: Jurnal Penelitian Pendidikan Agama Dan Keagamaan 10, no. 3 (2012). https://doi.org/10.32729/edukasi.v10i3.169.

Kartiko, Ari, and jaya Roza Azzukhrufi. 'Pengaruh Budaya Organisasi Dan Kompensasi Terhadap Kinerja Pendidik Di Madrasah Aliyah Nahdlatul Ulama Mazro'atul Ulum Paciran'. Nidhomul Haq : Jurnal Manajemen Pendidikan Islam 4, no. 2 (5 September 2019): 207-26. https://doi.org/10.31538/ndh.v4i2.351.

kasmir. Manajemen Sumber Daya Manusia Teori Dan Praktik. Jakarta: Rajawali Pers, 2012.

Kusumaningrum, Desi Eri, Raden Bambang Sumarsono, and Imam Gunawan. 'Problematika

Pemberdayaan Dan Pengembangan Sumber Daya Manusia Di Sekolah Menengah Pertama Berbasis Pesantren'. Ilmu Pendidikan: Jurnal Kajian Teori Dan Praktik Kependidikan 2, no. 2 (29 December 2017): 139-50. https://doi.org/10.17977/um027v2i22017p139.

lijan poltak s. Manajemen Sumber Daya Manusia. Jakarta: Bumi aksara, 2016.

Ma`arif, Muhammad Anas. 'Analisis Konsep Kompetensi Kepribadian Guru PAI Menurut Az-Zarnuji'. ISTAWA 2, no. 2 (2017): 35-60.

Maarif, Muhammad Anas, and Muhammad Husnur Rofiq. 'Pola Pengembangan Kurikulum

Pendidikan Pesantren Berkarakter: Studi Implementasi Pendidikan Berkarakter di Pondok Pesantren Nurul Ummah Mojokerto' 13 (2018): 16.

Mohamad, Mustari. Manajemen Pendidikan. Jakarta: RajaGrafika Persada, 2014.

Muktaf, Zein M. 'T Eknik Penelitian Studi Kasus , Etnografi Dan Fenomenologi Dalam Metode Kualitatif', 2016, 1-5.

Prabu, Anwar. Manajemen Sumber Daya Manusia. Jakarta: Rineka Cipta, 2011. 
P.Siagian, Sondang. Manajemen Sumber Daya Manusia. Jakarta: Pt. Bumi Aksara, 2009.

Raharjo, Sabar Budi. 'Evaluasi Trend Kualitas Pendidikan Di Indonesia'. Jurnal Penelitian Dan Evaluasi Pendidikan 16, no. 2 (2013): 511-32. https://doi.org/10.21831/pep.v16i2.1129.

Rohman, Miftahur. 'PROBLEMATIKA GURU DAN DOSEN'. Cendikia: Jurnal Pendidikan Dan Kemasyarakatan Vol.14 No. (2016): 49-71.

Simamora. Rekrutmen Dan Seleksi. Jakarta: Pt.Bukan Bintang, 2014.

Sinambela, Lijan Poltak. Manajemen Sumber Daya Manusia / Lijan Poltak Sinambela; Editor, Suryani. Ed. 1 cet. 1. Bumi Aksara, 2016.

Trianto dan Titiek Triwulan. Sertifikasi Dan Upaya Peningkatan Kualifikasi Kompetensi Kesejahteraan Guru. Jakarta: Prestasi Pustaka Publisher, 2014.

Yani, M. Manajemen Sumber Daya Manusia. Jakarta: Mitra Wacana Media, 2012. 